\section{低熱ポルトランドセメントを用 いた高強度高流動コンクリート の構造体品質の均一性に関する 調查 \\ DIAGNOSIS OF THE QUALITY OF STRUCTURE MADE OF HIGH PERFORMANCE CONCRETE WITH LOW-HEAT PORTLAND CEMENT}

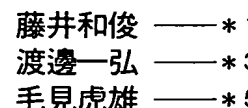

キーワード

低熱ポルトランドセメント，高強度高流動コンクリート，櫡造体品質，圧縮強 度, 粗骨材面樌率, 中性化深さ

Keywords

Low-heat portland cement, High-strength and high-fluidity concrete, Quality in structures, Compressive strength, Rate of coarse aggregate area, Carbonation depth

\section{Kazutoshi FUلII - $* 1$ Hiroyasu NARUSE $-* 2$ \\ Kazuhiro WATANABE $-* 3$ Hirokazu NAKASE $-* 4$}

On the demolition of an existing structure made of high-strength and highfluidity concrete, we determined various quality parameters and their variations by place. Parameters included compressive strength, Young's modulus of elasticity and coarse aggregate distribution by the sampled core, and concrete fill capability and carbonation depth of surfaces cut by wire-sawing. Uniformity of the quality of the structure was evaluated by the variance analysis of the data. It was found that the quality of the high performance concrete was acceptable though the slight variation in a structure was observed.

\section{1.はじめに}

高強度高流動コンクリートは、その特性から一般の建築物のみな らず鉄筋コンクリート造建築物の高層化・大型化の傾向に伴って、 建築分野でも高強度のマスコンクリート部材へ次第に利用されつつ ある。

高強度コンクリートでは、粉体量が多く、水和発熱が多くなり、 水和発熱に起因するひびわれが生じるため、マスコンクリート部材 に適用するためには水和発熱の少ない低熱ポルトランドセメントな どが多く用いられている。また、低熱ポルトランドセメントは、低 温での初期強度発現がやや小さいほかは、良好な硬化コンクリート の性質を示すことや流動性がよいことなどからもその使用は増大す るものと考えられる。しかしながら低熱ポルトランドセメントは、 1997 年に JIS 化されたばかりで、構造用としての歴史が浅い。この ため、高強度コンクリートにおいては、初期材齢に高温履歴を受け た場合、長期にわたる強度発現にどのような影響があらわれるかに ついては、まだ十分には明らかにされていない1。

一方、高流動コンクリートは、自由流動距離が長いと鉄筋間を通 過する際、粗骨材とモル夕ルが分離し、流れの先端部では粗骨材量 の少ないコンクリートとなる恐れがある。これらについても、実大

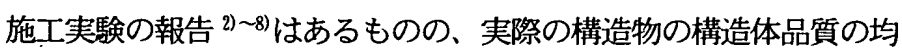
一性についての調査は、計画的にコアを採取することが困難なこと から、その報告は少ないと考えられる。
今回対象となる建物が再開発地域にあることから、約 5 年半経過 した低熱ポルトランドセメントを用いた高強度高流動コンクリート 構造物をワイヤーソーイングで解体する機会を得た。

本報告は、高強度高流動コンクリートを使用した高密度配筋のマ スコンクリート部材となる実際の構造物(反力壁)から採取したコア の圧縮強度、ヤング係数、粗骨材面積率およびワイヤーソーイング で切り出した切断面のコンクリートの充填性や中性化深さを調査す るとともに、さらに压縮強度と粗骨材面積率の各特性值に及ぼす反 力壁の横、幅および高さ方向の影響について分散分析を行い、構造 体品質の均一性について検討したものである。なお、本構造物の建 設時の品質は、既に技術報告集第 5 号 9)に報告したものである。

\section{2. 解体した構造物の概要 ${ }^{9}$}

\section{1 構造物の概要}

解体した構造物は、横 $8 \mathrm{~m} \times$ 高さ $8 \mathrm{~m} \times$ 幅 $2 \mathrm{~m}$ の反力壁である。 反力壁の配筋は、D32〜25@125〜250mm ダブル である。また、 幅方向に実験治具定着孔用スリーブが $500 \mathrm{~mm}$ ピッチで設けられて いる。コンクリートの打設は、1995 年 9 月 14 日〜 10 月 9 日にわた り 6 層に分けて行った。今回の調査対象範囲は、リフト高さが同 一の第 2 〜第 5 リフトとした。

\section{2 構造物の形状ならひに切断位置とコア採取位置}

構造物の形状、ワイヤーソーイングによる切断位置およびコア採

\footnotetext{
1 三菱建設森捕研究所 室長・博士 (工学)

（テ349-0224 埼王県白岡町彦兵衛54）

*2 (㑣宇部三菱セメント研究所主席研究員

*3 三菱建設脷捕研究所 主任研究員・工修

*1 三菱建設体東京建築支店 主任

*5 ものつくク大学 非常勤講師・I博
}

*1 General Manager, Technical Research Institute, Mitsubishi Construction, Dr. Eng.

*2 Chief Research Engineer, Ube-Mitsubishi Cement Research Institute, Corporation

*3 Senior Research Engineer, Technical Research Institute, Mitsubishi Construction, M. Eng.

*4 Engineer, Construction Group, Tokyo Branch, Mitsubishi Construction

*5 Lecturer. Monotsukuri Institute of Technology, Dr. Eng. 


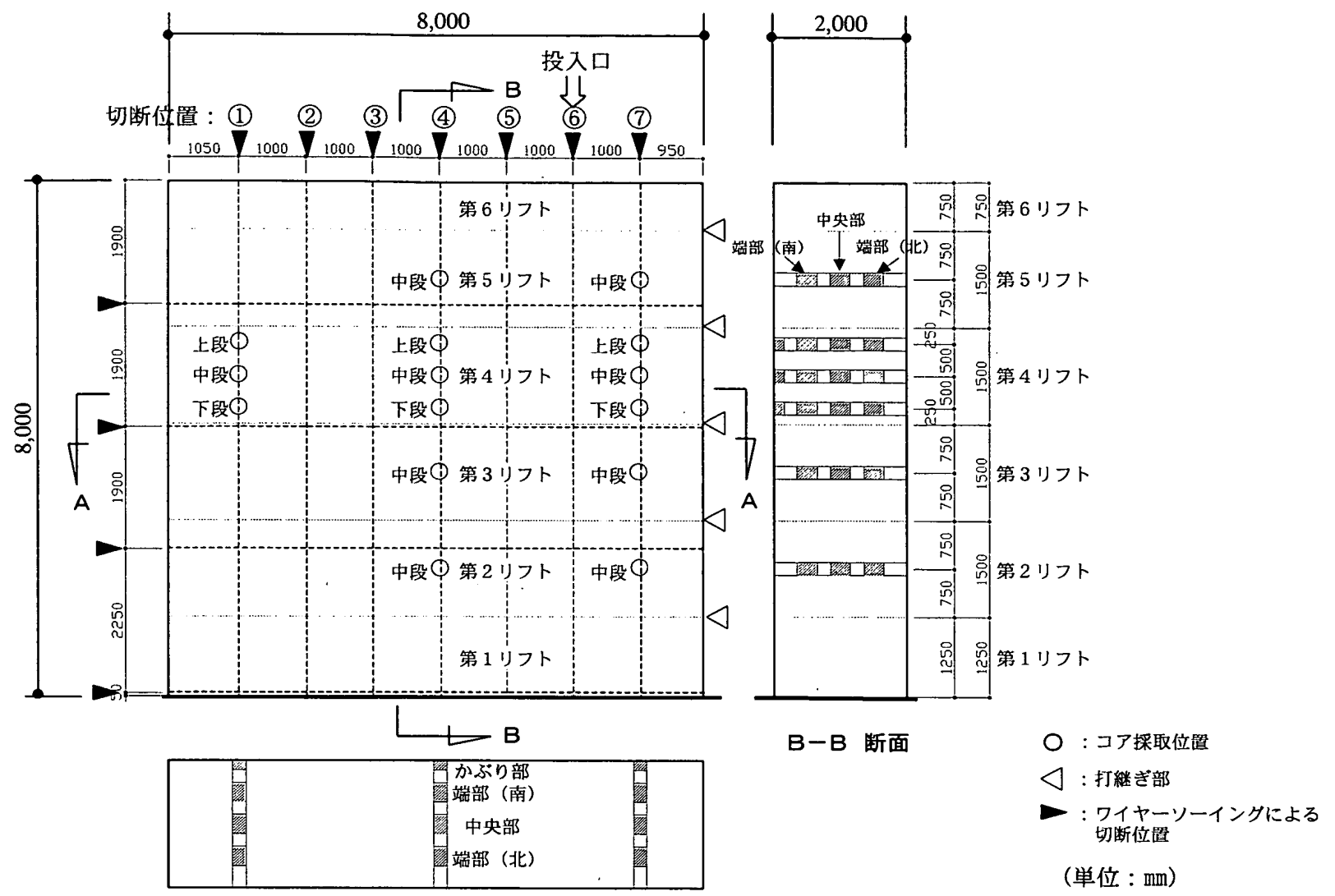

A-A 断面

図ー 1 構造物の形状、ワイヤーソーイングによる切断位置およびコア採取位置

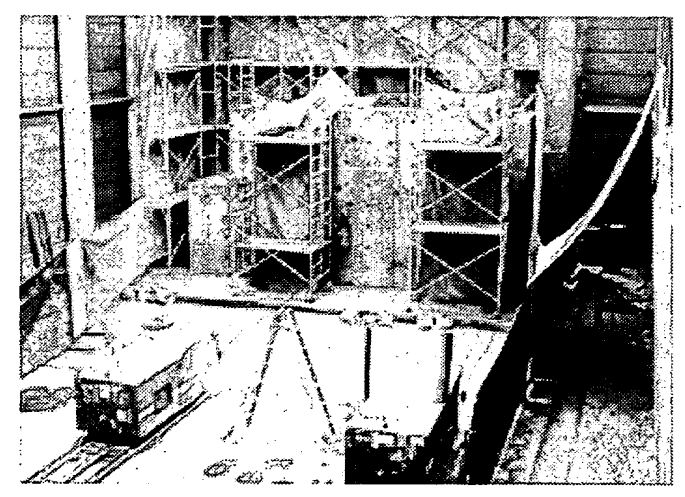

写真 -1 構造物の解体状況

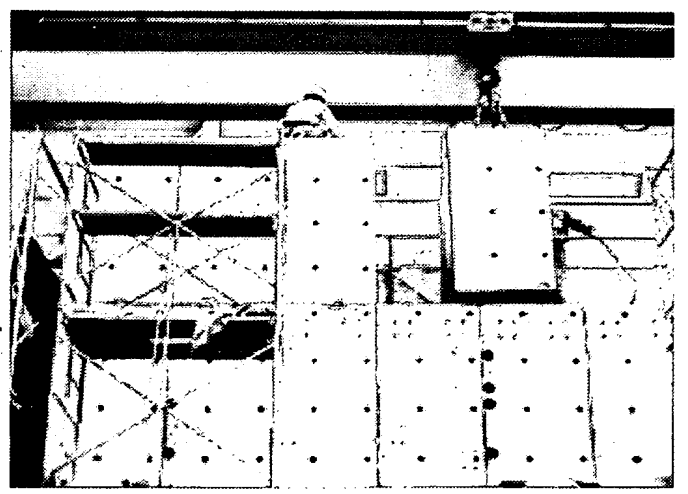

写真 -2 構造物の搬出状況
取位置を図-1、コア供試体のカット位置を図ー 2 、構造物の解体 状況を写真 -1 、搬出状况を写真 -2 に示す。

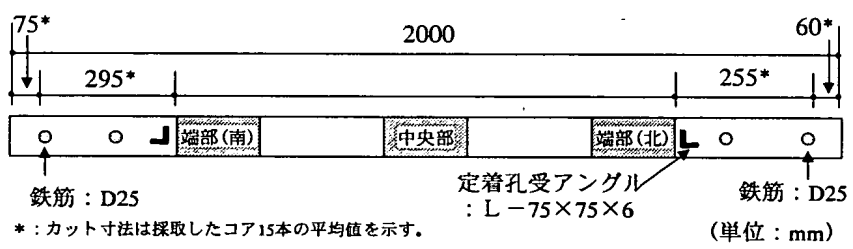

図ー－２コア供試体のカット位置

\section{3 使用材料および調合}

使用材料を表 -1 、計画調合を表一 2 に示す。目標とするスラン プフローは $650 \pm 50 \mathrm{~mm}$ 、空気量は $4.5 \pm 1.5 \%$ とした。

表 -1 使用材料

\begin{tabular}{|c|c|}
\hline 使用材料 & 種類及び物性 \\
\hline セメント & $\begin{array}{l}\text { 低熱ポルトラントセメント (L) } \\
\mathrm{CS}_{2} \text { 量 } 60 \% \text {,密度 }: 3.24 \mathrm{~g} / \mathrm{cm}^{3} \text {, 比表面積: } 3040 \mathrm{~cm}^{2} / \mathrm{g}\end{array}$ \\
\hline 粗骨材 & $\begin{array}{l}\text { 鍋山産石灰岩砕石 } \\
\text { 表乾密度: } 2.71 \mathrm{~g} / \mathrm{cm} 3 ， \text { 吸水率: } 0.74 \%\end{array}$ \\
\hline 細骨材 & $\begin{array}{l}\text { 鍋山産石灰岩砕砂 } \\
\text { 表乾密度: } 2.68 \mathrm{~g} / \mathrm{cm} 3 \text { ，吸水率: } 1.46 \% \text { ，粗粒率: } 3.3 \\
\text { 香取郡産山砂 } \\
\text { 表乾密度 }: 2.58 \mathrm{~g} / \mathrm{cm} 3 \text { ，吸水率: } 2.01 \% ， \text { 粗粒率: } 1.8\end{array}$ \\
\hline 混和剂 & 高性能AE減水剂 (ポリカルボン酸系) \\
\hline 分離低減剤 & 水溶性セルロースエーテル系 \\
\hline
\end{tabular}


表ー2 コンクリートの計画調合

\begin{tabular}{|c|c|c|c|c|c|c|c|}
\hline \multirow{3}{*}{$\begin{array}{l}\mathrm{W} / \mathrm{C} \\
(\%)\end{array}$} & \multicolumn{7}{|c|}{ 単位昆 $\left(\mathrm{kg} / \mathrm{m}^{3}\right)$} \\
\hline & \multirow{2}{*}{ セメント } & \multirow{2}{*}{ 水 } & \multicolumn{2}{|c|}{ 細骨材 } & \multirow{2}{*}{ 粗骨材 } & \multirow{2}{*}{$\begin{array}{l}\text { 混和剤 } \\
(\mathrm{C} \times \%)\end{array}$} & \multirow{2}{*}{$\begin{array}{c}\text { 分踓低減戍 } \\
\left(\mathrm{g} / \mathrm{m}^{3}\right)\end{array}$} \\
\hline & & & (研砂) & (山砂) & & & \\
\hline 45.0 & 367 & 165 & 460 & 438 & 929 & 2.2 & 300 \\
\hline
\end{tabular}

\section{4 構造物建設持の涀定結果}

1) コンクリートの測定結果

建設時のポンプ质送後のフレッシュコンクリートの試験結果を表 - 3、硬化コンクリートの試験結果を表一 4 に示す。

促進中性化試験は、日本建築学会の「コンクリートの促准中性化 試験方法(案)」に準拠して行った。

\section{2) 温度履歴}

各リフトの中心部に熱電対を設置した。温度履歴の実測結果を図 -1 に示す。各層の温度履歴は、同様な傾向で事前に行った解析値 と概社一致していた。

表ー3 フレッシュコンクリートの試験結果

\begin{tabular}{c|c|c|c|c}
\hline \multirow{2}{*}{ 試験項目 } & \multicolumn{4}{|c}{ 各リフトの試験結果 } \\
\cline { 2 - 5 } & 2 & 3 & 4 & 5 \\
\hline スランプフロー $(\mathrm{mm})$ & $560 \times 555$ & $580 \times 595$ & $665 \times 650$ & $590 \times 565$ \\
\hline フロー50cm時間 (秒) & 5.1 & 5.3 & 3.1 & 6.2 \\
\hline 空気量 (\%) & 3.6 & 5.1 & 5.8 & 5.7 \\
\hline コンクリート温度(C) & 22.1 & 25.2 & 25.4 & 21.8 \\
\hline 外気温 (C) & 22.9 & 21.3 & 25.5 & 18.1 \\
\hline
\end{tabular}

\begin{tabular}{|c|c|c|c|c|c|}
\hline 表-4 & \multicolumn{5}{|c|}{ 硬化コンクリートの試験結果 } \\
\hline \multirow{2}{*}{ 試験項目 } & \multirow{2}{*}{ 試験材砱 } & \multicolumn{4}{|c|}{ 各リフトの試験結果 } \\
\hline & & 2 & 3 & 4 & 5 \\
\hline \multirow{5}{*}{$\begin{array}{c}\text { 標淮美生の } \\
\text { 质縮強度 } \\
\left(\mathrm{N} / \mathbf{m m}^{2}\right)\end{array}$} & 3 日 & - & 13.6 & - & - \\
\hline & 7 日 & - & 19.6 & - & - \\
\hline & 28日 & 38.0 & 33.7 & 31.0 & 36.7 \\
\hline & 56日 & - & 41.6 & - & - \\
\hline & 91日 & - & 48.1 & - & - \\
\hline \multirow{5}{*}{$\begin{array}{c}\text { ヤング俰数 } \\
\left(\times 10^{4} \mathrm{~N} / \mathrm{mm}^{2}\right)\end{array}$} & 3 日 & - & 1.99 & - & - \\
\hline & 7 日 & - & 2.21 & - & - \\
\hline & 28日 & 3.13 & 2.77 & 2.67 & 2.91 \\
\hline & 56日 & - & 3.02 & - & - \\
\hline & 91日 & - & 3.20 & - & - \\
\hline 促進中性化深さ $(\mathrm{mm})$ & 26週 & - & 15.2 & - & - \\
\hline
\end{tabular}

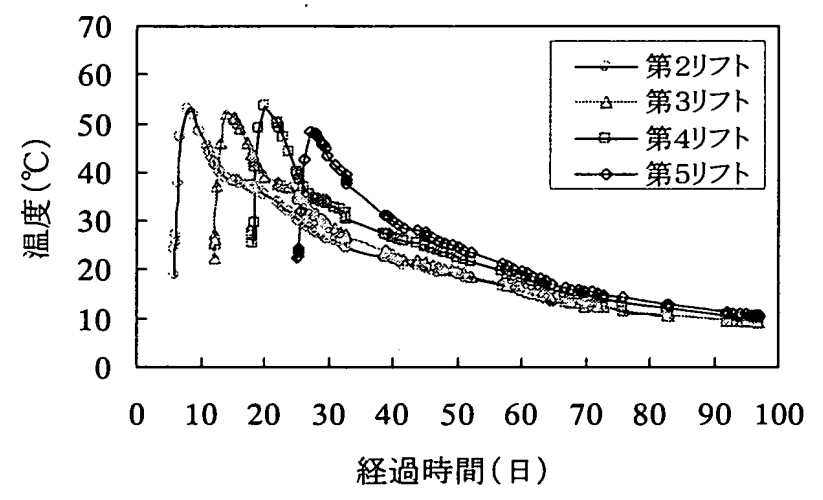

図-3 温度履歴

\section{3. 試験項目之試験方法}

\section{1 币綃強度とヤング係数}

压縮強度の測定は、材踰 5 年 5 ケ月で採取したコア供試体につい てJIS A 1107 に準じて行い、ヤング保数は圧縮強度の $1 / 3$ で計算 した。コアは圧縮強度試験夷施 4〜 5 日前より採取を開始し、2 日 前に成形を完了して、強度試験まで標潐養生を行った。

\section{2 粗骨材面積率}

粗骨材面積率の測定は、採取したコアの傾面にフイルムを張り付 け、骨材断面を楕円近似し、長軸長さが $5 \mathrm{~mm}$ 以上の骨材を写し取っ て行った。

\section{3 中性化梁さ}

ワイヤーソーイングによる切断面に $1 \%$ \%エノールワタレイン溶 液を塗布し、中性化深さを測定した。

\section{4. 実験結果と考察}

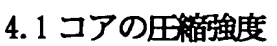

\section{(1)第4リフトのコアの正䌟强度}

第4リフト切断面(1)，(4)，(7)の圧緶強度試験結果を図一4に、第 4 リフト切断面(1)，(4)，(7)の圧縮強度の横、幅および高さ方向位置 の三元分散分析結果を表 -5 に示す。

表－5より第4リフト切断面(1), (4)，(7)の王縮強度は、横方向に ついては 5 \%有意となったが、幅方向および高さ方向については、 有意差は認められない。流動距離と考えられる横方向については図 -4に示すようにその差は小さく、既往の実験結果 ${ }^{4)}$ 之同様な結果 で、問題となる差異ではないと考えられる。

(2) 各リフトのコアの压栯強度

各リフト切断位置(4)，(7)の中段の王縮強度を図一 5 に、各リフト 切断位置(4)，(7)の中段の圧縮強度の横、幅方向および各リフトの位 置の三元分散分析結果を表一 6 に示す。

表一 6 より各リフト切断位置(4)，(7)の中段の圧縮強度は、各要因 とも有意差がなかった。

(3) 全コアの因粕強度

全コアの瓦縮強度の平均值は $60 \mathrm{~N} / \mathrm{mm}^{2}$ と、標準養生 28 日の圧縮強 度の約 1.7 倍であった。また、全コアの標準偏差は、 $4.4 \mathrm{~N} / \mathrm{mm}^{2}$ 、変 動保数 $7.4 \%$ と既往の実験結果 (4) 之同様な結果で、構造体コンクリー トの均一性は確保されているとみなせる。
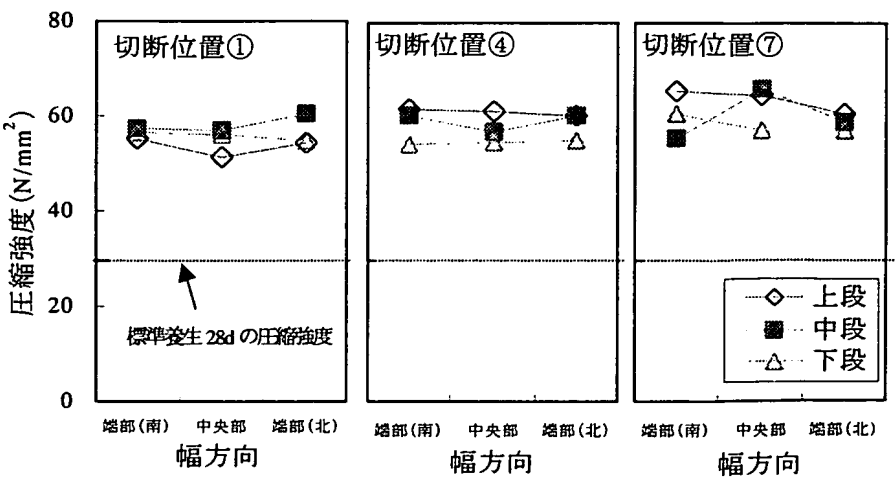

図-4 第4リフトのコアの爪縮強度 

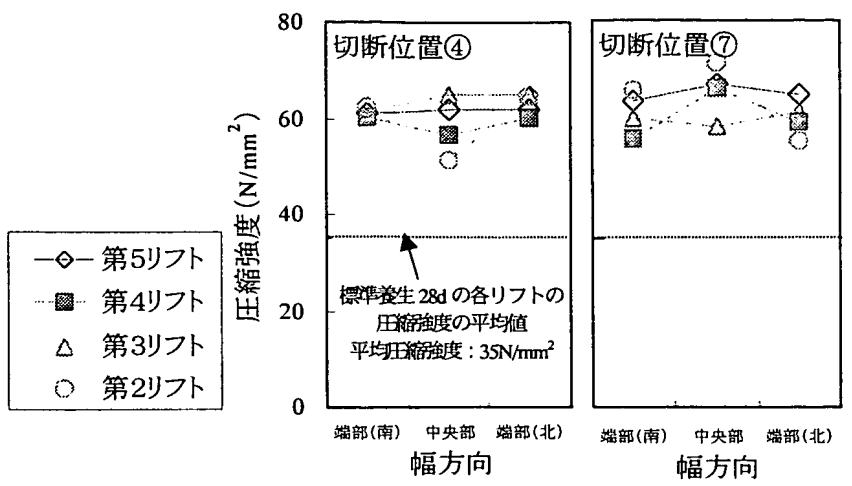

図ー5 各リフトのコアの圧縮強度

表-5 第4リフトコアの压縮強度の横（切断位置）、 幅および高さ方向の三元分散分析結果

$* *: 1 \%$ 有意 $*: 5 \%$ 有意

\begin{tabular}{|c|c|c|c|c|c|c|}
\hline 要 因 & 偏差平方柇 & 渞 由 & 度平均平 & $\mathrm{F}$ 值 & 值 & 判定 \\
\hline A:横方向 & 108.11 & 2 & \begin{tabular}{l|l} 
& 54.05 \\
\end{tabular} & 7.6924 & 0.0137 & $*$ \\
\hline B:幅方向 & 1.52 & 2 & 0.76 & 0.1079 & 0.8990 & \\
\hline C:高さ方向 & 58.09 & 2 & 29.05 & 4.1336 & 0.0585 & \\
\hline $\mathrm{A} \times \mathrm{B}$ & 27.35 & 4 & 6.84 & 0.9729 & 0.4730 & \\
\hline$A \times C$ & 85.88 & 4 & 21.47 & 3.0552 & 0.0837 & \\
\hline$B \times C$ & 19.22 & 4 & 4.81 & 0.6839 & 0.6226 & \\
\hline 謖差 & 56.22 & 8 & 7.03 & & & \\
\hline 全体 & 356.38 & 26 & & & & \\
\hline
\end{tabular}

表一6 各リフトコアの压縮強度の横（切断位置）、 幅方向および各リフトの三元分散分析結果

**: $1 \%$ 有意 $*: 5 \%$ 有意

\begin{tabular}{l|c|c|c|r|r|r|}
\hline 要 因 & 偏差平方和自由 用平均平月 $\mathrm{F}$ 值 & \multicolumn{1}{|c|}{ 值 } & 判定 \\
\hline $\mathrm{A}:$ 横方向 & 7.65 & 1 & 7.65 & 0.251 & 0.6342 & \\
\hline $\mathrm{B}:$ 幅方向 & 3.91 & 2 & 1.96 & 0.0642 & 0.9385 & \\
\hline $\mathrm{C}:$ 各リフト & 39.53 & 3 & 13.18 & 0.4323 & 0.7377 & \\
\hline $\mathrm{A} \times \mathrm{B}$ & 101.74 & 2 & 50.87 & 1.669 & 0.2653 & \\
\hline $\mathrm{A} \times \mathrm{C}$ & 64.70 & 3 & 21.57 & 0.7075 & 0.5817 & \\
\hline $\mathrm{B} \times \mathrm{C}$ & 36.06 & 6 & 6.01 & 0.1972 & 0.9656 & \\
\hline 誤差 & 182.88 & 6 & 30.48 & & & \\
\hline 全体 & 436.46 & 23 & & & & \\
\hline
\end{tabular}

\section{2 円絔強度とヤング保数}

圧縮強度とヤング係数の関係を図ー6に示す。

採取したコアのヤング係数は、田縮強度が高くなると大きくなる 傾向があるが、バラツキが大きい。 $\mathrm{RC}$ 規準10)では、ヤング係数は NewRC 式の保数 $\mathrm{k} 1=\mathrm{k} 2=1.0$ として示されており、 $\mathrm{k} 1 、 \mathrm{k} 2$ は使用 骨材、混和剤により適切な值を用いてもよいとされている。本研究

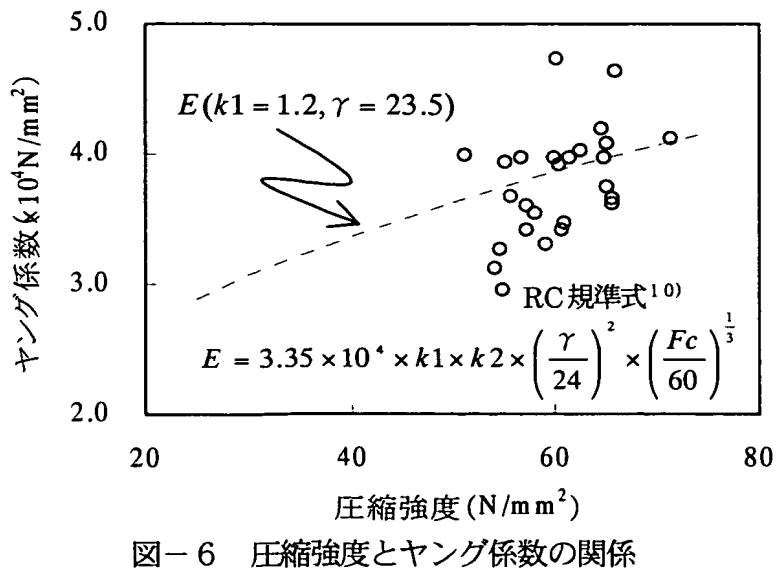

の供試体では、石灰岩研石であるので $\mathrm{k} 1=1.2$ とし、 より 23.5 として計算した結果を図ー6中に破線で示した。計算結果 は、本研究で採取したコアのヤング倸数のほほ平均的な值となった。

\section{3 粗骨材面積率}

(1)第 4 リフトのコアの粗骨材面積率

第4リフト切断面(1)，(4)，(7)の粗骨材面積率を図-7に、第4リ フトの粗骨材面積率の横、幅および高さ方向位置の三元分散分析結 果を表一 7 に示す。

第4リフトの粗骨材面積率は、表－7より各要因とも有意差なし となり、一様なものとみなせる。また、粗骨材面積率の平均値は $34.2 \%$ あ゙あり、これは調合上の粗骨材容積率である $34.3 \%$ に近い值 であった。

(2)各リフトのコアの粗骨材面積率

各リフト切断位置(4)，(7)の中段の粗骨材面積率を図一 8、各リフ 卜切断位置(4)，(7)の中段の粗骨材面積率の横、幅方向および各リフ 卜の位置の三元分散分析結果を表一 8 に示す。

各リフトの粗骨材面積率の平均值も $34.2 \%$ 、これも調合上の粗 骨材容積率に近い值であった。また、表一8より各リフト切断位置 (4)，(7)の中段の粗骨材面積率は、各要因とも有意差なしとなり、各 リフトの粗骨材面積率もほほ一様なものとみなせる。

\section{(3)かぶり部の粗骨材面積率}

かぶり部分と中央部の粗骨材面積率の関係を図ー9に示す。

かぶり部分の粗骨材面積率は、既往の実験結果 ${ }^{111}$ 之ほぼ同様な結 果で中央部の 70〜80\%となり、中央部の粗骨材面積率に比べて全て のリフトで小さくなった。このことは、過密配筋の影響が大きいと 考えられるが、特に $50 \mathrm{~cm}$ フロー時間が 3.1 秒と小さく、スランプフ ローが $665 \times 650 \mathrm{~mm}$ と大きい第4リフトのかぶり部分の粗骨材面積 率が、小さくなった。
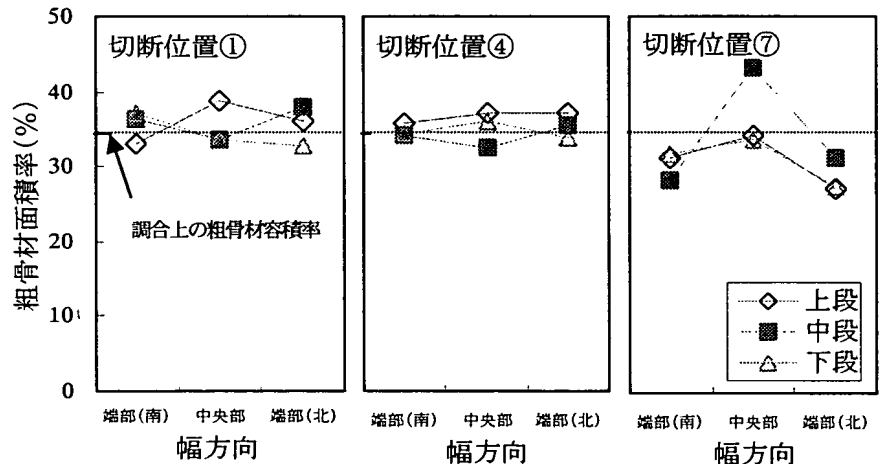

図-7 第4リフトのコアの粗骨材面積率

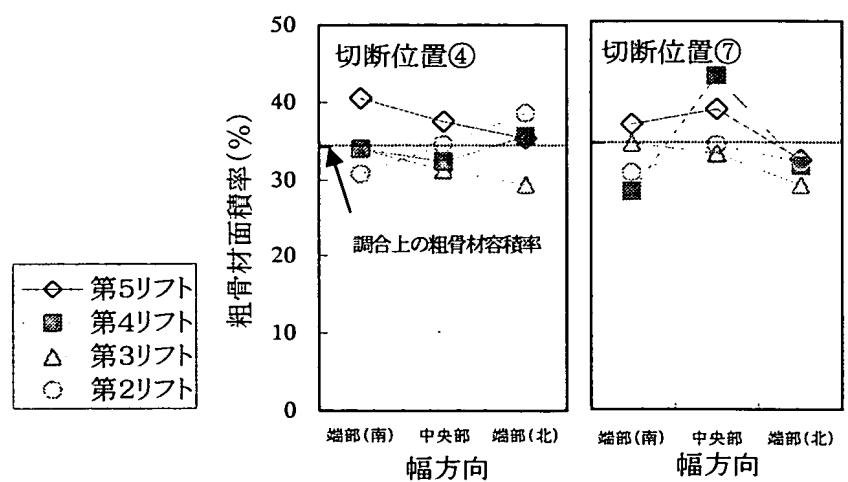

図-8＼cjkstart各リフトのコアの粗骨材面積率 
表一７第4リフトコアの粗骨材面積率の横（切断位置） 幅および高さ方向の三元分散分析結果

$* *: 1 \%$ 有意 $*: 5 \%$ 有意

\begin{tabular}{|c|c|c|c|c|c|c|}
\hline 要 因 & 偏差平方 & 宙 & 酷平均平 & $F$ & $\mathrm{P}$ & 面判定 \\
\hline $\mathrm{A}:$ 横方向 & 66.21 & 2 & \begin{tabular}{l|l}
33.11 \\
\end{tabular} & 3.5436 & 0.0791 & \\
\hline B:幅方向 & 35.66 & 2 & 17.83 & 1.9088 & 0.2100 & \\
\hline C:高さ方向 & 8.89 & 2 & 4.45 & 0.4760 & 0.6378 & \\
\hline$A \times B$ & 82.10 & 4 & 20.53 & 2.1971 & 0.1595 & \\
\hline $\mathrm{A} \times \mathrm{C}$ & 28.73 & 4 & 7.18 & 0.7689 & 0.5746 & \\
\hline $\mathrm{B} \times \mathrm{C}$ & 22.79 & 4 & 5.70 & 0.6100 & 0.6671 & \\
\hline 詥差 & 74.74 & 8 & 9.34 & & & \\
\hline 全体 & 319.13 & 26 & & & & \\
\hline
\end{tabular}

表－8 各リフトコアの粗骨材面積率の横（切断位置） 幅方向および各リフトの三元分散分析結果

$* *: 1 \%$ 有意 $*: 5 \%$ 有意

\begin{tabular}{c|c|c|c|c|c|c|c}
\hline 要 因 & 偏差平方和自 由 博平均平方 & $\mathrm{F}$ & 值 & $\mathrm{P}$ & 值 & 判定 \\
\hline $\mathrm{A}:$ 横方向 & 4.38 & 1 & 4.38 & 0.5171 & 0.4991 & \\
\hline $\mathrm{B}:$ 幅方向 & 31.08 & 2 & 15.54 & 1.8353 & 0.2388 & \\
\hline $\mathrm{C}:$ 各リフト & 76.77 & 3 & 25.59 & 3.0225 & 0.1155 & \\
\hline $\mathrm{A} \times \mathrm{B}$ & 54.90 & 2 & 27.45 & 3.2422 & 0.1110 & \\
\hline $\mathrm{A} \times \mathrm{C}$ & 9.92 & 3 & 3.31 & 0.3907 & 0.7643 & \\
\hline $\mathrm{B} \times \mathrm{C}$ & 91.21 & 6 & 15.20 & 1.7955 & 0.2473 & \\
\hline 誤差 & 50.80 & 6 & 8.47 & & & \\
\hline 全体 & 319.04 & 23 & & & & \\
\hline
\end{tabular}

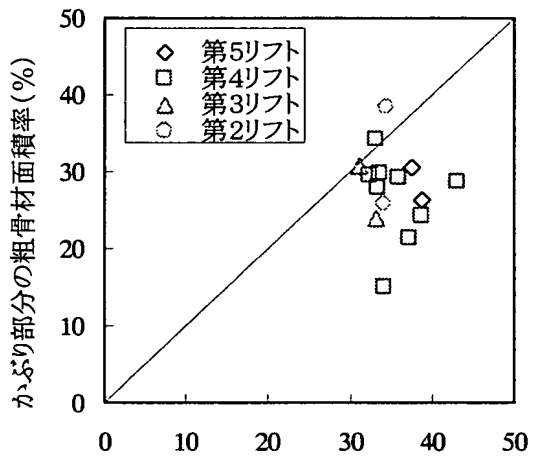

中央部の粗骨材面積率 (\%)

図-9 かぶり部分と中央部の粗骨材面積率の関係

\section{4 粗骨材面積率と田縮強度およびヤング保数}

粗骨材面積率之压縮強度の関係を図一 10 に、粗骨材面積率とヤ ング俰数との関係を図 -11 に示す。

粗骨材面積率と圧縮強度との関係は認められないが、粗骨材面積 率が小さくなるとヤング保数も小さくなる傾向が見られた。

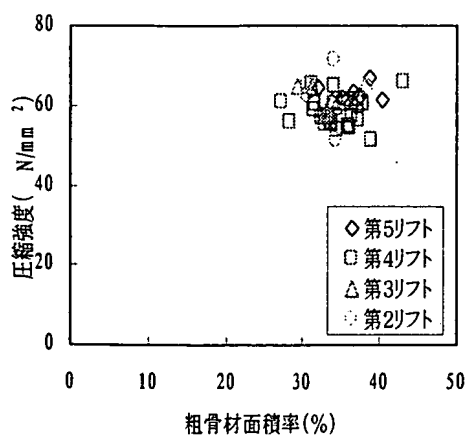

図- 10 粗骨材面積率と 圧縮強度の関係

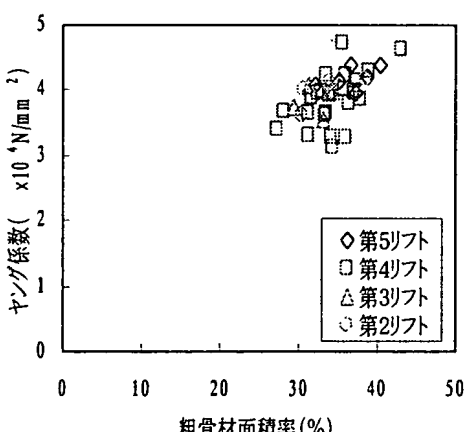

図- 11 粗骨材面積率と ヤング係数の関係

\section{5 中性化深さ}

（1）各リフトの中性化深さ

各リフトの中性化深さを図-12 に示す。各リフトの中性化深さは、 コア抜きを行っていない切断位置(1)の第 2 ・ 3 リフトを除くと約

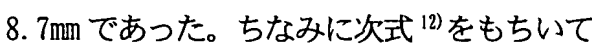

$$
C=A \sqrt{\mathrm{CO}_{2} / 5} \cdot \sqrt{t}
$$

$\left(C:\right.$ 中性化深さ $(\mathrm{mm}), \mathrm{CO}_{2}$ : 炭酸ガス濃度(\%), $\mathrm{A}:$ 中性化速 度係数 $(: \mathrm{mm} \cdot$ 週-0.5), $t:$ 材路命週)

表一 4 に示す材齢 26 週の促進中性化試験 ( $\mathrm{CO}_{2}$ 濃度 $\left.5 \%\right)$ の結果 $15.2 \mathrm{~mm}$ から中性化速度係数を求めると 3.0 となり、この值と今回測定した 中性化深さ $8.7 \mathrm{~mm}$ および中性化試験までの材齢 280 週から $\mathrm{CO}_{2}$ 濃度 を試算すると $0.14 \%$ となり一般の屋内濃度の 1.4 倍となる。このこ とは、反力壁は屋内にあり、冬期実験中に採暖のためにジェットヒ 一ターを用いたことによる乾燥や屋内の炭酸カスス濃度が高くなった ことも原因と考えられる。

\section{（2）打継さ部の中性化深さ}

打継ぎ部の中性化深さを図一 13 に示す。打継ざ部の中性化深さは、 一般部に比べて大きい。特に下リフト打継ぎ部は一般部の約 4 倍、 上リフト打継ざ部の約 2 倍と中性化深さが大きい。これらを模式的 に示すと図ー14 となる。この原因については更に検討が必要と考え られるが、文献 ${ }^{13}$ よると高強度高流動コンクリートの場合、ブリー ディングが少なく、表面の乾燥が早まることが多く、表首部がポー ラスになって耐久性が低下する危険性が助長されることが指摘され ている。この対策としては、コンクリートの上面の十分な湿潤養生 が重要となる。また、打放し構造物での一体打込み、もしくは打継 ぎ部の炭酸ガスの進入防止のための処理が必要であると考えられる。
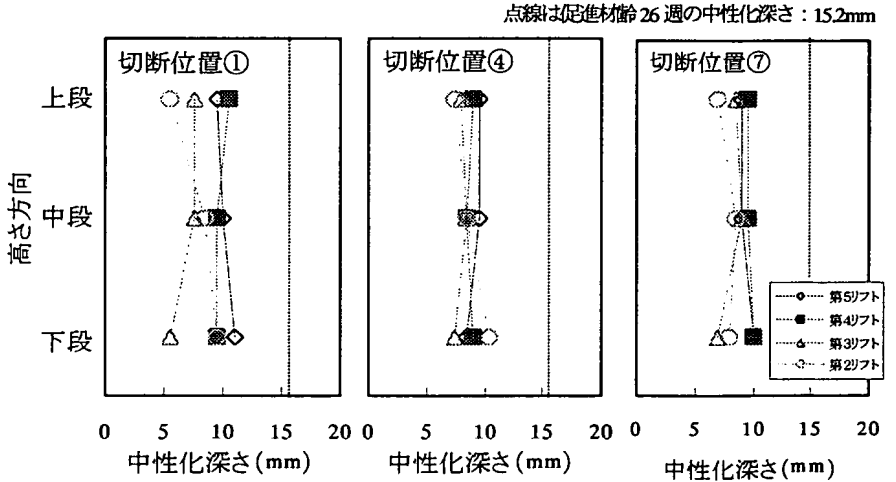

図-12 各リフトの中性化深さ

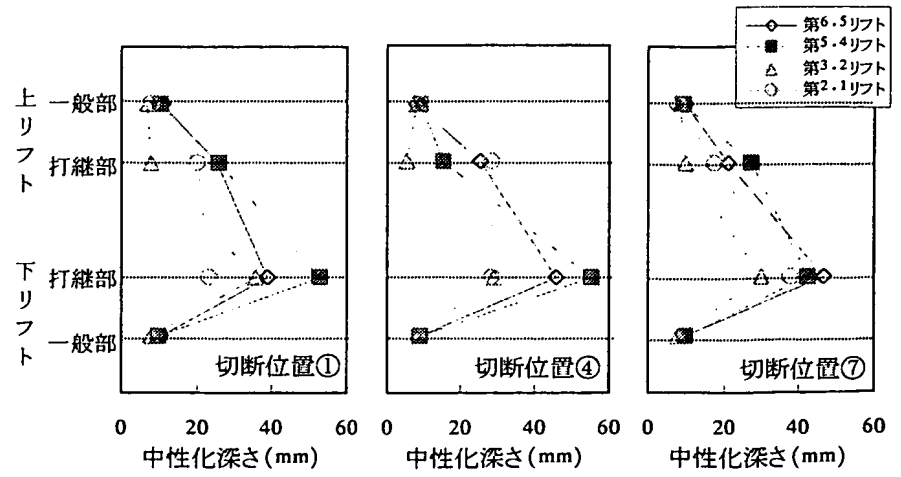

図-13 打継ざ部の中性化深さ 


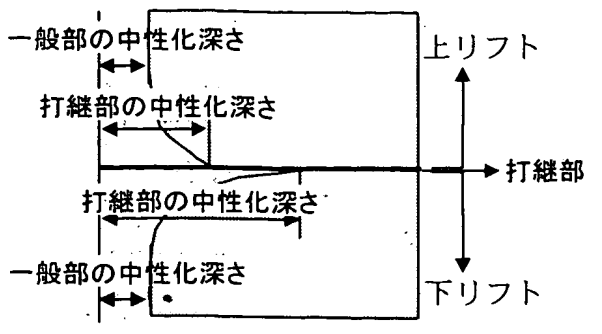

図-14＼cjkstart打継ぎ部の中性化深さの模式図

\section{6 鉄筋周りなどのコンクリートの充填性}

鉄筋周りの充填状况の一例を写真一 2 に、定着孔受けアングル周 りの充填状况の一例を写真一 3 に示す。

全ての切断面において目視観察できた鉄筋周りおよび定着孔受け アングル周りのコンクリートの充填性は、良好であった。
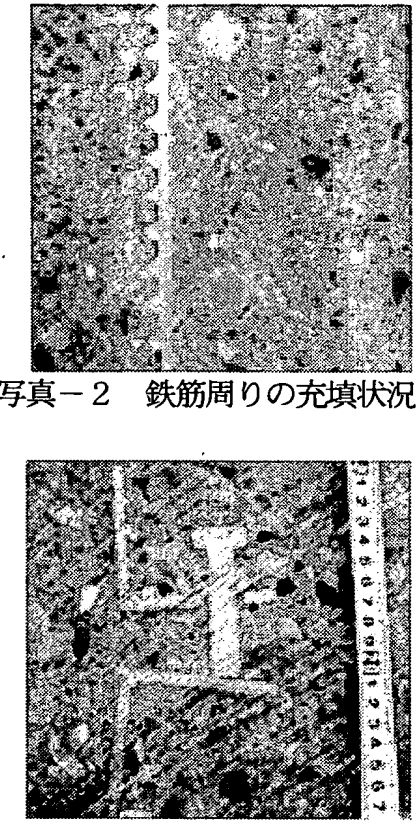

写真-3 定着孔受けアングル周りの充填状况

\section{5. まとめ}

本研究の結果をまとめると, 以下の通りである。

（1）コアの压縮強度は、第4リフトの横方向については $5 \%$ 有意とな ったが、それ以外は横、幅および高さ方向と各リフトの各要因とも 有意差がなかった。

（2）全コアの压縮強度の平均值は $60 \mathrm{~N} / \mathrm{mm}^{2}$ と、標淮養生 28 日の圧縮 強度の約 1.7 倍であった。また、全コアの標準偏差は、 $4.4 \mathrm{~N} / \mathrm{mm}^{2}$ 、 変動係数 7.4\%で、構造体コンクリートの均一性は確保されていると みなせる。

（3）採取したコアのヤング係数は、压縮強度が高くなると大きくな る傾向があるが、バラツキが大きい。

（4）粗骨材面積率は、調合上の粗骨材容積率である $34.3 \%$ に近い値 であり、各要因とも有意差なしとなり、粗骨材面積率はほぼ一様な ものとみなせる。

（5）かぶり部分の粗骨材面積率は、中央部の 70 ～80\%となり、中央 部の粗骨材面積率に比べて全てのリフトで小さくなった。

(6) 各リフトの中性化深さの平均值は、約 $8.7 \mathrm{~mm}$ であった。打継ざ部
の中性化哚さは、一般部に比べて大きく、特に下リフト打継ぎ部の 中性化深さは、一般部の約 4 倍、上リフト打継ざ部の約 2 倍であっ た。

(7) 全ての切断面において目視観察できた鉄筋周りおよび定着孔受 けアングル周りのコンクリートの充填性は、良好であった。

\section{謝辞}

本研究を進めにあたり, ヒロセ化学 広瀬 美孝氏、システムエン ジニア(株) 柳沢 敦志氏ならびに松田 祐基子氏に協力をいただきま した。哚く感謝を申し上げます。

\section{参考文献}

1) 杉山央、桝田佳寛 : 早強および低熱ポルトランドセメントを用い たコンクリートの強度発現性に及ぼす初期高温履尓の影響, 日本建 築学会構造系論文集，No. 520，PP9～16, 1999. .

2）宇仁菅康行, 毛見虎雄，藤井和俊，小長光公和，中瀬博一，明石 峰子, 鳴瀬浩康 : 高流動・高強度コンクリートの実大施工実験（そ の3），日本建築学会大会学術講演梗概集 A, PP 385～386，1995.8 3）上西隆、田村博、大橋正治、木村芳幹 : 砕石粉使用高流動コンク リートの実大施工実験 (その 11), 日本建築学会大会学術講演梗概集 A, PP69 70, 1996.9

4）弦田康平、和泉意登志、井上和政、阪西康、牧保峯、三浦義雅、 三浦豊司 : 新タイプの高流動コンクリートの開発(その8), 日本建 築学会大会学術講演梗概集 A，PP95～96，1996.9

5）小沼和仁、伊藤正人、林伯健、蓮見昌之、佐藤正明、石田浩： 分離低減剤を用いた高流動コンクリートに関する実験研究 (その 18）, 日本建築学会大会学術講演梗概集 A, PP183～184，1997.9 6) 和泉意登志、本多幸武、佐野寛、早川光敬、芝池達司、立山創一、 寺田謙一: 高流動コンクリート実大施工実験(その 1), 日本建築学 会大会学術講演梗概集 A，PP319～344，1995

7) 周建東、中田善久、西山直洋、平石信也、葉賀忠昭、笠井芳夫 : フローイングコンクリートに関する実験研究 (その 26), 日本建築学 会技術講演梗概集 A，PP227〜228，1996

8）中瀬博一, 毛見虎雄, 藤井和俊, 小長光公和, 宇仁菅康行, 鳴瀬 浩康，柳澤敦志 : 実大壁による高流動コンクリートの施工性に関す る実験的研究 (その 2), 日本建築学会大会学術講演梗概集 A, PP601 $\sim 602, \quad 1994.9$

9）山本祐基子, 毛見虎雄, 藤井和俊, 宇仁菅康行, 渡浐一弘、中嶋 和子 : 低熱セメントを用いた高流動コンクリートのマスコンクリー 卜部材への適用, 日本建築学会技術報告集 第 5 号 PP12〜17, 1997. 12

10）日本建築学会:鉄筋コンクリート構造計算規準 ・同解説 一許容 応力度設計法一、P38〜 40, 1999

11) 坂田昇、中下兼一、深田敦宏、万木正弘：高流動コンクリートの 配合が施工性及び充填性に及ぼす影響、コンクリート工学年次論文 報告集、Vol. 15, No1, PP131 136, 1993

12）日本建築学会: 高耐久性鉄筋コンクリート造設計施工指針(案) · 同解説, P87, 1991.

13）日本建築学会: 高流動コンクリートの材料 - 調合 - 製造 - 施工指 針(案) ·同解説、P127, 1997

[2001年10月17日原稿受理２002年 2 月18日採用決定］ 